\title{
TEACHING CLASSICAL SOCIOLOGICAL THEORY IN SINGAPORE: THE CONTEXT OF EUROCENTRISM*
}

\begin{abstract}
We argue that there is a need to rethink the teaching of classical sociological theories given our concern with the limitations of the received theoretical canon, and through our encounters with students of sociology who also persistently ask that the classics be shown to be meaningful and of contemporary relevance. In our teaching, we highlight Eurocentrism as an additional and essential context for understanding the rise of classical sociological theory, and to attune students in more meaningful ways to the works of Marx, Weber, and Durkheim. Ironically, such an approach constitutes a new form of legitimating the classics by revealing their timeless qualities, notwithstanding their Eurocentrism.
\end{abstract}

\section{Syed Farid Alatas National University of Singapore}

\author{
VineEta SinHa \\ National University of Singapore
}

WHY READ OR TEACH the works of Marx, Weber, and Durkheim, or other European authors long departed to a class of Singaporean or Southeast Asian students? What have the ideas of three European theorists, born in the last century, in a different cultural milieu, to do with the Southeast Asia of today?

The issue of the relevance or applicability of the social sciences to non-Western contexts has been raised by scholars across a wide variety of disciplines since the 19th century (S.H. Alatas 1956; Fei [1947] 1979; Rizal [1890] 1962; Sarkar [1937] 1985). It has also been noted that the social sciences emerged amidst specific historical conditions and cultural practices, a recognition that should lead to a critique of received theories and methods and the creation of original perspectives (S.H. Alatas 1972; 1974; 1979; Bennagen 1980; Blake 1991).

While the various calls for alternative

*Please address all correspondence to the authors at the Department of Sociology, National University of Singapore, Singapore 117570, Republic of Singapore; e-mail: socsfa@nus.edu.sg (Syed Farid Alatas) and socvs@nus.edu.sg (Vineeta Sinha)

Editor's note: The reviewers were, in alphabetical order, Jay R. Howard and Christine Ingraham. discourses (S.H. Alatas 1981; Atal 1981; Bell 1994; Ben Jelloun 1974; Khatibi 1967; Zawiah 1994) have in theory noted Eurocentrism and Orientalism in the social sciences, they have so far been unable to displace them in practice. Presently, many social scientists are engaged in at least the dual task of tertiary education as well as personal research. The critique of the social sciences that emanated from academic institutions in Asia, Africa, and Latin America tend to remain at an abstract and reflexive level. ${ }^{1}$ Neither have these calls manifested themselves at the level of teaching in the social sciences. In fact, there is sufficient evidence for the great gulf between undergraduate teaching and the realm of research. ${ }^{2}$

This is not to suggest that sociologists

\footnotetext{
${ }^{1}$ There have been several thoughtful pieces on the state of the various disciplines, raising the issue of the lack of connectedness between the social science and the societies in which they are taught (S.H. Alatas 1972; 1974; Asante 1990; Atal 1981; Fu 1993; Lie 1996; Uberoi 1968). The calls to decolonise the social sciences were generally not followed by successful attempts to build "indigenous" theories or autonomous social science traditions delinked from the academic core of Western Europe and North America.
} 
have not critically addressed problems in the teaching of the classics. In Teaching Sociology and other journals, several pieces addressing colonial and global topics appeared in the 1990s. Many of them, however, discuss these topics within a specifically American context and are not necessarily concerned with reorganizing sociological theory courses (for example, Lie 1995; Martin 1996). Those that do deal with the content of sociological theory syllabi are also generally writing within an American or British context (see Lewis and Alshtawi 1992; Parker 1997). The present paper further develops the idea of what has been referred to elsewhere as a multicultural sociology (Dumont 1995; Parker 1997) by outlining our experience in teaching classical sociological theory in a novel way.

An essential component of sociological training in most universities is the teaching of classical sociological theory. No doubt all students of sociology have at some point encountered Marx, Weber, and Durkheim as the "founding fathers" of their discipline. What constitutes sociological theory is generally defined as the particular writings of a set of European scholars, names with which most social scientists are familiar. Starting from a rather large pool, central, male Western figures have emerged and are consistently viewed as forefathers of sociology. Furthermore, in mainstream discourse, the social sciences are defined and accepted as being of "Western" origin. This is institutionalized as common wisdom not just in Western academic circles but also in the non-West. ${ }^{3}$ The rationale for rethinking the teaching of sociological theory is not only grounded in our theoretical concerns but also in our encounters with sociology students. Generally speaking, undergraduate

\footnotetext{
${ }^{2}$ See note 4.

${ }^{3}$ There are, however, some scholars (albeit a minority) who problematize the taken-forgranted definition of the social sciences as "Western" disciplines (Alatas 1993; 1995; Sanda 1988; Sinha 1997). Conceptually and ideologically, we consider this to be a legitimate research agenda.
}

students consider social theory to be "dry, dull and boring, intimidating, and full of jargon." Frequently, the label "irrelevant" is also heard in this connection, even in the West itself (Parker 1997). The following question is then logically raised: how can social theory be made interesting and relevant?

Additionally, the issue of teaching "Western" sociological theory in a nonWestern context to non-Westerners adds a critical dimension to the subject. Of course, a more universalistic approach to the study of sociological theory would have to raise the question of whether it is possible to identify examples of sociological theorizing outside of Western/European responses to modernity. The example of the 14th century Arab scholar, Ibn Khaldun, comes to mind. Recognition of theoretical insight in Ibn Khaldun's work would imply changes in sociology theory curricula. Nevertheless, it is not our contention that the recognition of contextuality requires that Western sociological theory be deleted from sociology curricula in non-Western universities. Rather, we argue for a fresh approach to teaching classi$\mathrm{cal}$ sociological theory that attunes students in more meaningful and critical ways to the works of Marx, Weber, and Durkheim. Ironically, such an approach constitutes a new form of legitimating the classics by revealing their timeless qualities, notwithstanding their various conceptual and methodological limitations.

This paper proceeds as follows. We begin by stating the rationale of rethinking the theory course given our critique of Eurocentrism. This is then followed by a description of the classical theory course that we reformulated and co-taught. Finally, we document and review student responses to the newly structured course as evinced from classroom discussions, and thus reflect on the value and effect of teaching classical sociological theory in this different mode.

\section{RETHINKING SC3101: THE CONTEXT OF EUROCENTRISM}

Classical sociological theory courses are 
taught in Asian countries without due recognition of the historical context and cultural practices of the students who enroll in these courses. The emphasis is on the context of the rise of sociological theories in Europe, dealing with issues that may bear little historical relevance or cultural meaning to our students. It is often noted that sociological theory arose as a result of thinkers reflecting upon social forces and problems, such as political revolutions, the industrial revolution and the rise of capitalism, urbanization, and the growth of science (Ritzer 1983:68). ${ }^{4}$

In general, we discern two fundamental problems with such syllabi. First, nonWestern founders or precursors of social thought and social theory are generally left out of the course outlines. Second, classical sociological theory is not contextualized in a manner that establishes a relevant reference point for students everywhere. While European enlightenment, the transition from feudalism to capitalism, and democratization in Europe, and so on, form a relevant context

\footnotetext{
${ }^{4} \mathrm{~A}$ glance at the course outlines of undergraduate sociological theory courses in a number of universities in Asia shows that theory is taught in much the same way as it is offered in a British or North American university. For example, the classical sociological theory (M1040) syllabus of the department of sociology, National Taiwan University is devoted to the study of Auguste Comte, Karl Marx, Friederich Engels, Herbert Spencer, Ferdinand Toennies, Emile Durkheim, Georg Simmel, Max Weber, and Vilfredo Pareto (For more information contact Alatas). At the department of sociology, University of Dhaka, a compulsory course for the Bachelors of Social Science in sociology, history of sociology (Soc 301 ), covers very much the same ground in addition to the inclusion of more contemporary theorists such as Karl Mannheim, Talcott Parsons, Robert Merton, George Herbert Mead, and others (University of Dhaka 1988: 18-20). An elective course, history of Western social thought (Soc 311), does, ironically, include Ibn Khaldun, while there is a separate course on non-Western thinkers in India and Bangladesh history of social thought in the orient with particular reference to India and Bangladesh Soc
}

for understanding the emergence of sociological theory, we argue that the historical fact of European political and cultural domination of non-Europe from the 15th century onwards is a crucial additional context. The latter is seldom given any space, let alone equal weight, in conventional teaching of classical theory. As is well known, this domination resulted, among other things, in the implantation of European social sciences in non-European societies, whether these societies were colonized by the Europeans or not (Dube 1984; Karim 1984; Kyi 1984; Rana 1984). Furthermore, and more importantly, it was in the period of European colonial domination that the European classical theorists wrote not only about their own societies but the "Orient" as well. Often, their analysis and reflections on nonWestern societies were as much statements on the "Occident" as they were on the "Orient." Such a realization suggests the need for a different and critical approach to teaching classical sociological theory. In our reconstruction of the syllabus for SC 3101, ,

312 (University of Dhaka 1988: 43-50). Soc 311 and Soc 312 are both elective courses, however. At the University of Delhi, sociological theory (Paper V) covers only Marx, Weber, Durkheim, Parsons, and Merton (University of Delhi). The department of sociology at the University of Jordan offers a sociological theory course covering Ibn Khaldun, Comte, Spencer, Durkheim, Toennies, and Gabriel Tarde (For more information contact Alatas). By and large, non-Western thinkers are not included. Neither is sociological theory contextualised differently in comparison to how it is taught in North America and Europe. The above is also true of SC 3101 (social thought and social theory), offered as a compulsory module to third (final) year sociology majors at the National University of Singapore, as it was taught in previous years.

${ }^{5}$ The course consisted of 23 lectures taught over 13 weeks. The class size per semester averaged about 160 students. The students broke into groups of about 10 and would meet with us for a total of 10 tutorial sessions, in the course of the semester. The primary pedagogical strategy was the tutorial. During each of the 10 tutorial sessions, each of which lasted an hour, selected 
we highlight in this paper the problem of Eurocentrism $^{6}$ as one of several central biases in the existing sociological canon.

Given our theoretical interests and teaching experiences, we formulated an alternative mode of introducing sociological theory given our non-Western teaching location. Nevertheless, the new version is equally appropriate for Western universities, dealing as it does with biases that must be corrected in any context. Using Marx, Weber, and Durkheim as our starting point, we aimed to ask the question: How can we teach the sociological canon to incorporate both our theoretical concerns and the needs of our students?

Bearing in mind these concerns, we begin with the theme of Eurocentrism as a crucial point of orientation. A cautionary word on our usage of the term "Eurocentrism" is necessary. As we understand the term, it signifies far more than its literal and commonplace meaning, "Europe-centeredness." We hold that Eurocentrism connotes a particular position, a perspective, a way of seeing and not-seeing that is rooted in a number of problematic claims and assumptions. We also did not want to ourselves essentialize by assigning to the three theorists the same, generalized usage of the label "Eurocentrism." In fact, we quite consciously strived to establish the specific and different ways in which aspects of the theories under consideration may or may not be Eurocentric. We are aware, furthermore, that the recognition of Eurocentrism in the writings of Marx, Weber, and Durkheim is

topics from the lectures and course readings were assigned and discussed at some length. The student responses included in this paper are derived from discussions we had with our students during the tutorials. The full course outline, including the lecture and tutorial schedules, is available upon request from the authors.

${ }^{6}$ When we taught the same course the second time around, we included Harriet Martineau as one of the four classical theorists in our attempt to address the bias of androcentrism in classical sociological theory. Unfortunately, we are unable to give equal treatment to androcentric bias neither a surprise nor a recent discovery. Yet despite the datedness of this theme in the social sciences, the critique of Eurocentrism has not meaningfully reshaped the ways in which we theorize the emergence of the classical sociological canon. So despite "knowing" that some aspects of Marx's, Weber's, and Durkheim's writings are "Eurocentric," and expectedly so, the issue of how this impacts our contemporary reading of their works remains largely unaddressed and untheorized.

In an effort to deal with these issues, we assign an essay by Wallerstein on Eurocentrism (1996). Through this paper, we alert students to the complexity and multidimensionality of the concept. This includes attention to Eurocentric historiography, definitions of progress, the claims to uniqueness of European civilization and capitalism, and the problem of Orientalism. We also aim to demonstrate that social science theories assume that the development of modern capitalist society in Europe was not only good, but would be replicated elsewhere, and that therefore, scientific theories are valid across time and space.

We contextually locate the issue of European political, economic, and cultural domination of the non-West in the very emergence of sociological theory itself. We then raise a series of related questions: How have colonial and imperial encounters shaped conceptualization in the social sciences by Western scholars? How have these writers imagined both the "non-West" and the "West?" How are we to assess and gauge classical sociological theories given the pos-

in the social sciences here in this paper. In a separate written piece: "Reading Harriet Martineau: Parallels in Counter-Androcentric and Counter-Eurocentric Discourses," (2000) Vineeta Sinha has documented more comprehensively our experiences of introducing women social thinkers and theorists in the teaching of theory. We fully recognize and endorse the need to give equal emphases to these two biases, and to pay attention to the ways in which they further intersect-something we intend to incorporate in developing the course further. 
sibility of different kinds of biases, including a Eurocentric bias?

In posing these questions, we operate on the premise that a creative approach to sociological theory that imparts a level of meaning to the students hitherto unexperienced, should incorporate these three interrelated objectives: (1) to generate consciousness of "Eurocentrism" as a theme and context that informs classical sociological theory, (2) to demonstrate the utility of theory for the recovery of our past (Singapore or Southeast Asia) from Eurocentric accounts of it, and (3) to demonstrate the utility of theory for the understanding of contemporary realities in areas and regions closer to home. Our teaching approach was above all influenced by the first of these objectives. ${ }^{7}$ The need to reorient the course in this way is held to be all the more important because we note that Eurocentrism is not only found in European scholarship, but has affected the development of the social sciences in non-Western societies in a number of ways: (1) the lack of knowledge of our own histories as evidenced in sociology textbooks, (2) through Eurocentrism, images of our society are constructed which we come to regard as real until Eurocentric scholarship yields alternative images that may be equally Eurocentric, ${ }^{8}$ and (3) the lack of original theorizing. Because of the deluge of works on theory, methodology, and empirical research arising mainly from North America and Europe, there has been much consumption of imported theories, techniques, and research agendas. Bearing in mind these three problems, we suggested to students that they should (1) bear in mind the context in which sociological theory developed; (2) gauge its usefulness for the

\footnotetext{
${ }^{7}$ We plan to include Ibn Khaldun and other non-Western sociologists and social thinkers in future incarnations of this course, but these are not meant to replace Martineau, Marx, Weber, and Durkheim.

${ }^{8}$ It was widely believed that values, attitudes, and cultural patterns as a whole change in the process of modernisation, and that such changes were inevitable (Kahn 1979; Rudolph and
}

study of our own context (i.e., nonwestern); and (3) be aware of the Eurocentric aspects of sociological theory, which detracts from its scientific value.

In terms of teaching tools and strategies, the rethinking of this course entailed emphasizing those aspects of say, Marx's works that demonstrate his Eurocentrism, or selections of Weber's writings that either prove or invalidate similar charges levelled at him. For example, in addition to reading Marx's Contribution (1970) and Grundrisse (1973), we also chose to focus on Marx's discussion of the Asiatic mode of production and his discussions on colonialism in India (Marx and Engels 1968), themes that are routinely excluded in sociological theory courses. More importantly, through our treatment of these substantive issues, we further hoped to generate discussions about the effects of identifying Eurocentric biases in these works. Hence, we presented to our students the following reading vis-à-vis specific aspects of the works of Marx, Weber, and Durkheim.

\section{Marx}

While the section on Marx did deal with traditional topics such as the transition from feudalism to capitalism, circulation and production, alienation, class-consciousness, the state, and ideology, there was an attempt to work into the materials the three interrelated objectives referred to above. For example, we argued that the relevance of Marx's discussion on the transition from feudalism to capitalism is that it suggests that the presence of an emerging bourgeoisie in feudal society and a weak decentralized state in feudal societies were preconditions for the rise of capitalism. This in turn

Rudolph 1967). However, after the experience of high growth in East Asia in the 1980s and early 1990s, traditional cultural patterns such as those derived from Confucianism were offered as a factor explaining growth. With the onset of the Asian financial crisis in 1997, however, once again Confucianism and Asian values had become suspect for having a hand in the economic decline. 
implies that these preconditions were nonexistent in non-European societies. We pushed our students further with these queries: To what extent is this true, and to what extent is this a Eurocentric view?

Further, we asked whether in line with Eurocentric assumptions that Europe was unique, did Marx assume that such prerequisites were not to be found outside of Europe, and that precapitalist modes of production outside of Europe were obstacles to capitalist development? This question led to a discussion of Marx's Asiatic mode of production, particularly with reference to India.

Here we pointed out that Marx was often factually wrong about his characterization of "Asiatic" economies and societies, and that undergirding his political economy were Orientalist assumptions, which viewed nonEuropean societies as being the polar opposite of Europe. Bearing in mind the problematic nature of Marx's characterization of Indian society and his discussion of the Asiatic mode of production, we noted that despite this limitation, Marx's concept of the "mode of production" is extremely central to sociological analysis. Yet, recognizing the limitation is crucial as it informs even contemporary interpretations of his works, and perpetuates certain images of Asiatic and/or Indian society.

These discussions then made it possible to provide a more critical reading of Singapore's or Southeast Asia's past while retaining the universalistic aspects of Marxist theory. For example, an article on colonial ideology in British Malaya was assigned (Hirschman 1986). Here it was possible to demonstrate the utility of the Marxist concept of ideology for the critique of the Eurocentric aspects of colonial capitalism, of which Marx himself partook.

In addressing such topics as class consciousness, the state, and ideology, we included readings on contemporary Third World societies and on Southeast Asia in order that students might see the relevance of the ideas of Marx to regions other than his own. There was a concerted attempt, therefore, to expose Eurocentric elements in
Marx's writings while preserving the universal elements of his work as well as his larger theoretical contributions.

\section{Weber}

In our discussions of Weber's work, we explored two related themes: first, how Weber and his writings have been "Orientalized," and second, the nature of Weberian Orientalism or Eurocentrism, if indeed Weber is "Orientalist." In these conversations, we impressed upon the students that in evaluating Weber's work, we were not concerned only with Weber's intentions or his personal position, that is, with the question of whether Weber was himself Eurocentric or Orientalist. Our goal was also to ask if Weber's sociological writings revealed, or were embedded in Eurocentric and Orientalist assumptions, and how our answers would shape our subsequent interpretation of Weber's theoretical contributions.

According to Weber, the form that capitalism took in the West could only originate there because it required an attitude of commercial gain and profit that Weber called the spirit of capitalism, which he assumed was to be found in Protestant-dominated areas of Europe (Weber 1958a). Weber acknowledged that although Islamic and Confucian world views do stress frugality and hard work, the spirit of capitalism did not emerge in the Arab world or in China because of these missing elements: an ascetic compulsion to work, this-worldly asceticism, and the rationalization of life. In class, we asked if this reasoning revealed Eurocentric assumptions.

We also addressed how Third World scholars have received Weber's theories. The latter have generally assumed that for Weber, capitalism was an advanced, progressive economic system, and thus something "good and desirable," and following from this, that Western society was superior in this respect. Consequently, some nonWestern scholars have reacted defensively to Weber, and attempted to show that their own religions (Islam, Buddhism, Confucian- 
ism) were indeed conducive to the development of capitalism. We saw this as the "Orientalisation" of Weber's Protestant ethic theory in which Orientalist tendencies were attributed to the works of Weber. ${ }^{9}$

This led to a discussion on the relevance of Weber's Protestant ethic theory to Southeast Asia in which we attempted to rescue Weber from various misreadings, and highlighted the value of his sociology of religion for theorizing culture and development. For example, some class time was spent discussing the possibility that current interpretations of Confucianism and development tend to implicitly valorize a disenchanted world. Weber's views on objectivity and the social sciences, and his separation of fact and value were discussed as well (Weber 1969). We found them useful in clarifying the distinction between value-laden and Eurocentric social science.

Turning to the second theme, the nature of Weberian Orientalism or Eurocentrism, we discussed Weber's arguments about the origin of modern, rational capitalism in the West in The Protestant Ethic and the Spirit of Capitalism (1958a) by contextualizing this text in the larger corpus of his comparative sociology of religion. We then assigned selections from Weber's The Religion of India (1958b) and Religion of China (1951). Through attention to Weber's sociology of religion, we were able to abstract Weber's discourse on the specific socio-economic and cultural descriptions of "Western" and "non-Western" societies. For example, in looking at The Religion of India, we noted Weber's attention to caste and Hinduism as defining and distinct features of Indian society. We further pointed out that Weber's understanding of caste and Hinduism is informed by a textual reading that is problematic and provides some evidence for his essentializing and Orientalizing Indian society, in addition to a weak substantive account of the same. Similarly, Weber's account of Confucianism and Taoism in his

\footnotetext{
${ }^{9}$ On the Third World consumption of Weber, see Buss (1984).
}

Religion of China raises broader conceptual questions about the limitations of treating the Judeo-Christian notion of religion as a universal category of investigation; can Confucianism and Taoism be treated as religions in this sense? Furthermore Weber's characterization of Confucianism as "world affirming" and of Confucian rationalism as a "rational adjustment to the world," contribute to the image of Chinese society as static and unchanging or at least not inclined towards change. This again feeds into Orientalist constructions of the non-West as "passive," lacking a history, and ultimately "different" from the West.

Taken as a whole, we suggested that Weber's writing on the comparative sociology of religion does reveal specific Eurocentric biases. Parts of his writings were clearly ethnocentric (in interpreting other societies in terms of criteria drawn from the West) and also Orientalist (to the extent that he essentializes the West/non-West by emphasizing the differences between them, and through asserting the uniqueness of the European experience).

We also impressed upon our students that we do not find in Weber a simplistic notion of progress, and that Weber does not link the uniqueness, distinction, and singularity of Europe with a parallel notion of the progressive, civilizational superiority of Europe. Neither do we see in his work an attempt to impose a universalist history. We made the point that far from suggesting that other, non-European societies, should adopt capitalism, Weber was extremely explicit about the negative aspects of modern, rational capitalism. We emphasized that Weber's attitude towards capitalism and bureaucratic structures were ambivalent. Thus, despite the various substantive and methodological weaknesses in Weber, we nonetheless noted the value of his theoretical contributions; for example, Weber may have been mistaken about the nature of caste in India and about Confucianism in China, but his larger point about the relations and connectedness of religious, political, and economic structures is certainly worth pursuing. 


\section{Durkheim}

Continuing the theme of Eurocentrism, we asked if Durkheim's writings show any such signs. Comparing Marx and Durkheim on the issue of colonialism, we made the following observations. While Marx explicitly addresses colonialism and talks about its effects on a colony (India), Durkheim, in his sociological writings, remains silent on the subject of European imperial and colonial activities. What we find problematic in Marx is his treatment of British colonialism and its justification for the "progress" of Indian society. What is troubling in Durkheim is precisely his neglect of colonialism and conflict. Indeed, we are not saying that all sociologists must address the issue of colonialism in order to avoid the charge of being Eurocentric. We are not suggesting that Durkheim's mere neglect of colonialism and silence on this issue furnish evidence for his Eurocentrism. However, this silence does impact his theorizing of social change, both in the West and the non-West.

Durkheim conceptualizes social change as the transition from mechanical to organic solidarity, that is, from traditional to modern society. His proposal that this change is normal, natural, inevitable, spontaneous, desirable, and progressive is problematic. This theory is not only conceptually flawed but also ahistorical. Durkheim does not ask how colonialism might affect his theory of change. Neither does he seem to acknowledge that "real" historical societies did not change spontaneously and naturally, but that very often, change was imposed through external domination, conquest, and threat of violence. In fact, Durkheim's silence on colonialism leads one to speculate if he might actually view the devastating changes brought about through European colonial encounters with the non-West (which were viewed as tiaditional societies) as desirable and good because it led to differentiation, organic solidarity, and moral individualism-in a word, modernity.

In making a case for the continued contemporary relevance of Durkheim, we fo- cused on these three texts: Division of Labour in Society (1933), Suicide: A Study in Sociology (1952), and The Rules of Sociological Method (1895). We argued that Durkheim's methodological contributions to sociology are indeed immense, seeing his most lasting contribution carried in his question, What is the social? The latter continues to engage contemporary sociologists, who creatively debate about how to place boundaries around an entity labelled the "social." In addition to methodology, the impact of Durkheim's conceptual categories was also highlighted. Evidence was garnered to support the continuing relevance of such concepts as anomie, moral individualism, collective conscience, and mechanical and organic solidarity in theorizing contemporary societies. Students were asked to think about how Durkheim's ideas of mechanical and organic solidarity could be used to make sense of the "Shared Values" debate in Singapore. They were asked to apply Durkheim's concepts to an analysis of the state's efforts to forge a sense of common, national identity in the face of socio-cultural, religious, and economic differences within the citizenry. The question of searching for the social glue to bond people also has shades of Durkheim's "collective conscience." It was suggested that mechanical solidarity, premised on the perception of similarities between individuals, might continue to be relevant in societies that Durkheim may otherwise label modern. We assigned a provocative piece by Tiryakian (1994) on Durkheim and the "return" of mechanical solidarity to continue the discussion of Durkheim's relevance to the present.

\section{A Discussion of Student Responses}

In the previous section, we outlined how we tried to put into practice an alternate way of teaching the classical sociological canon through our lectures, tutorials, and assigned readings. We now move to a discussion on student responses to the course. The following discussion comes from two sources: tutorial discussions and student term papers. We selectively present the various student 
responses, some of which we anticipated and others which surfaced unexpectedly, in terms of the three interrelated objectives of the course referred to above.

\section{EUROCENTRISM}

During the first tutorial, students were introduced to the underlying theme of freedom in the works of Marx, Weber, and Durkheim. They were also asked to address the implications of Eurocentrism as a context for the rise of sociological theory. As expected, questions were immediately raised about what is meant by Eurocentrism, and what many students labelled as its "opposite"-an "Asian perspective." Some students were quick to point out that Eurocentrism had negative connotations, and that the corrective to Eurocentric approaches did not lie in taking an equally ethnocentric perspective from an Asian point of view.

Admittedly, there was a degree of confusion about what these various terms meant. For instance, some students wondered if everything European was Eurocentric. Many students interpreted Eurocentrism to mean a dominance of European things and ideas. Class discussions led to students asking of each other:

\section{Student 1: Are you Eurocentric?}

Student 2: Yes, to a large extent. But we don't have a choice. We didn't choose this...it was thrust upon us. So just bear with it. It's not voluntary. I have no choice.

Student 1: Are you sure? Maybe you like it.

This discussion brought to the fore those who self-defined themselves as Eurocentric and saw nothing "wrong" with it. One student thought herself to be Eurocentric with regard to the clothes she wore, the food she ate, the movies she watched, and the fact that she spoke English as a first language. She added that she was not ashamed of this. Was it not "better" and "good" that she was "Eurocentric"? She defended her position thus:
But my Eurocentrism can be explained. There is a reason for it. Like clothes. I like jeans and $t$-shirts because they are so comfortable.

To which another student replied somewhat sarcastically:

You mean tight jeans are more comfortable than a loose sarong, samfoo and sari?

Another student said of his Eurocentric (read "Western") preferences:

Quite good, what. Anyway the whole world likes jeans so it is not really Eurocentric but something like global centric.

Wallerstein's paper: "Eurocentrism and Its Avatars" (1996), helped to continue the discussion on Eurocentrism in our second tutorial. As expected, we did not achieve a consensus with regard to defining Eurocentrism, but we agreed to use Wallerstein's formulation as a useful starting point. Some rightly asked if some of the central questions raised by Western social scientists were not Eurocentric. For example, referring to the discussion the previous week, one student said:

Is the "problem of freedom" a true problematic for us? What is meant by freedom anyway? Isn't freedom an enlightenment ideal and so Western, thus European and Eurocentric? Is this a "problem" for everybody? The same can be said for democracy.

Continuing in this vein, other students wondered why we should be concerned with the problem of reason and freedom (the topics of the second lecture) and whether Europeans do not impose these ideals on "us."

Of the three theorists we read, Marx was most obviously seen as Eurocentric. Marx's portrayal of Indian society generated lively discussion:

How can Marx make fun of people praying to Hanuman and considering the cow a sacred animal?

What makes Marx think Europe is all good? 
What is so great about capitalism anyway? Didn't Marx think capitalism should be destroyed?

\section{Does he have double standards or what?}

These students and their somewhat emotional responses to Marx's letters to Engels (Marx and Engels 1968) concluded that it was essential to recognize Eurocentric biases in Marx as these affected how we continue to look at the West and the non-West. Since Marx had not visited India, and as his accounts were based on second-hand reports, did Marx produce only stereotypical images of Indian society? Others argued that at least Marx was not "hypocritical," since with different information about Indian society, he admitted his earlier mistaken views, as discussed in an assigned reading (Ghosh 1984). But they also saw that Marx's retraction only showed that he was wrong about the progressive role of colonialism, not that he thought Indian society could now successfully adopt a different historical development route from that of Europe. In this they saw absolute evidence of Marx's Eurocentrism.

Some even suggested that Marx's change in views did not necessarily signal that he adopted a non-Eurocentric stance, as we are still unclear as to whether he accepted the progressive role of colonialism in principle. At this point, we all realized the complexity of the problem of Eurocentrism in asking if the view that social change in Europe from feudalism to capitalism represented progress, was itself Eurocentric. In other words, if Europeans believed themselves to be progressive for having made this transition, does this belief in itself constitute Eurocentrism? What the class considered one possible answer to this was that what defines a belief or theory as Eurocentric is not the view that capitalism could only have originated in Europe or that capitalism was a progressive system, but rather the conviction in European superiority and the "white man's burden."

A further question then surfaced: If Marx's theories are Eurocentric, does it mean that his works are irrelevant? Our position was that there was much in Marx that continued to be of relevance. An awareness of Eurocentric elements in his work made it possible for us to pick out what was relevant. In fact, we were later able to distinguish between the factual and ideological statements contained in the concept of the Asiatic mode of production.

By our sixth tutorial, students were quick to pick up on what they saw as Eurocentric elements in the works of the classical theorists. Referring to the "Protestant Ethic thesis," most students concluded that Weber was Eurocentric because he regarded capitalism as a superior economic system that could only originate in Europe. Some even suggested that Weber used Protestantism to engage in propaganda for capitalism. Nevertheless, we were impressed that at least some students were perceptive enough to point out that such a view (even if falsely attributed to Weber) was reductionist because it did not consider the role of structural factors in the rise of capitalism in Europe. This does not preclude the possibility of the presence of the spirit of capitalism outside of Europe, or the possibility of capitalism with a different spirit from that found in Europe elsewhere. Later, the students were to learn that this view came close to Weber's own, and that Weber was not quite as Eurocentric in ways earlier assumed. In response to the question of whether it was justifiable to speak of a Weberian Orientalism (Tutorial 7), students understood that the fact that Weber saw modern capitalism as a uniquely European creation itself did not justify his being labelled an Orientalist, unless it was demonstrated that he held Eurocentric views such as the "double mission of British colonialism" (Marx and Engels 1968), and so on.

After having read some analyses, views, and comments of Marx and Weber on India and China, students were able to appreciate the different ways in which sociological theory could be Orientalist. For example, Marx was Orientalist in that he held to negative definitions of non-Western soci- 
eties, a case in point being that he defined India in terms of the absence of features present in Europe-such as private property. Weber, on the other hand, was Orientalist in his tendency to look at non-Europeans in homogeneous and undifferentiated terms. For example, this was how he saw Hinduism. Weber also tended to be textualist in his reading of Indian society in that he assumed Indian reality conformed to versions presented in the text, an assumption that he explicitly avoided in his analysis of Europe. There is also the question of the imposition of terms and concepts originating in a European setting, and their application in non-European contexts. For example, Weber used terms such as church and sect when discussing Hinduism and Islam. Weber was also guilty of essentializing as when, for example, he regarded Confucianism as the main value system in China. Thus, through the works of Marx and Weber, Eurocentrism was seen to be complex and multidimensional.

Having become familiarised with a Eurocentric account on the rise of capitalism, students were asked, in the second tutorial, to assess the claims made with regard to the relationship between Confucianism and development in East Asia in terms of their being Eurocentric or counter-Eurocentric. As expected, both arguments were made. Some students felt that the argument that Confucianism was conducive to economic development and that it was a factor in the rise of East Asia was counter-Eurocentric, whereas others came to a consensus that such an argument bought into Eurocentric notions of the superiority of capitalism, and therefore reinterpreted the role of Confucianism in development. It was even suggested in a discussion over our seventh tutorial, that such a view was the reverse of Orientalism (what some call Orientalism in reverse, or Occidentalism).

Our goal in highlighting the theme of Eurocentrism was to get students to think seriously about the problem of Eurocentrism without reacting emotionally and ethnocentrically to Western knowledge. By the end of the semester, students better understood Eurocentrism in terms of its various dimensions as pointed out in Wallerstein's essay (1996).

\section{THEORY FOR \\ THE RECOVERY OF OUR PAST FROM EUROCENTRIC ACCOUNTS}

It was interesting that the subject of colonialism, and particularly the colonial past of Malaya and Singapore, did not inspire a discussion of any significance with a majority of the students. Most of them seemed to view Singapore's colonial experience in rather benign terms. They also appeared to accept Malaya's and Singapore's past, as articulated in mainstream and "official" discourse. This could possibly be due to the way that colonial history has been so far presented and preserved in Singapore, where the British are perceived to have come, not as conquerors, but as harbingers of "progress." Even in our discussions of colonial and state ideology, most students did not appear to be able to theorize the power of these dominant ideologies in the past, and indeed, in the present. Most argued that if not for the British and the colonial episode, Singapore would not have become a modern and developed society.

Both in tutorial discussions and in essays, we repeatedly encountered the familiar discourse about Singapore being a small island, a fishing village with little or no natural resources until the British came and modernized it. Very few students attempted to construct Singapore through ancient or colonial history. Most contemporary narratives of "modern" Singapore begin with its "founding" by Sir Stamford Raffles as a British trading post in 1819. The year and the name are synonymous with the very existence of Singapore, particularly in historical reconstructions of the island's past by local political elites. Our students recounted the official history. They did not find it odd that a European man, a colonizer, should be crowned the founder of Singapore. Also, no one mentioned Malay sources as well as those in other non-English languages for Singapore history. Few students seemed fa- 
miliar with the notion of an alternative history of Southeast Asia, the rest of Asia, or of Europe, for that matter. Most, on the other hand, carried rather fixed, stereotypical notions about what constitutes Europe, China, India or Singapore, both today and in the past. This was evident in our discussions about "modernity" and its relationship to the non-West. Most saw Europe or the West as the locus of modernity and its transmission to the rest of the world.

It was in this context of the understanding of the past that the notion of ideology and its relationship to the ruling class was introduced in class. There were some students, however, who did problematize the official history of Singapore. They questioned whether the British had been "good" for Singapore and whether "progress" and "modernity" can only be achieved with capitalism and industrialization. While some suggested that the proclamation of Raffles as a "hero" was due to gratitude on the part of Singaporeans, others understood it as a product of the ideas of the ruling class. Nevertheless, how the image of Raffles fits into the ideology of postcolonial capitalism in Singapore remained vague for the class.

On the utility of Weber for the study of the historical role of religion in Southeast Asian development, students generally failed to note that it was less Weber's views on the Protestant ethic and capitalism than the relationship between religion and economy that was important. In discussing the applicability of Weber to Southeast Asia, some had thought that Weber was irrelevant, as he wrote on Protestantism while Protestantism was not a major religion in the region. It was then necessary to make a distinction between Weber's specific statements on the Protestant ethic and the theoretical implications for the study of religion and capitalism.

\section{THEORY FOR THE UNDER- STANDING OF CONTEMPORARY REALITIES IN AREAS AND REGIONS CLOSER TO HOME}

The question of "relevance" necessarily surfaced in view of our discussion that Marx,
Weber, and Durkheim were European scholars, concerned most explicitly with theorizing the profound changes occurring in Western society.

Many students thought that Marx was "wrong" in his account of capitalism, its impending destruction, and the anticipated polarization of society into two classes. Indeed, most saw capitalism as a universal mode of production as well as a "good thing," and wondered what Marx meant by the "evils of capitalism." They observed that capitalism had not disappeared, that the middle classes had burgeoned in contemporary society, and that most of the world is now capitalist. Many had difficulty agreeing with Marx about the issue of "pauperization." Questions such as these were typical:

Are workers in Singapore really that bad off?

Is capitalism that evil?

What is wrong with capitalism anyway?

How can the capitalist be exploiting the workers? He also has to take some risks by investing through capital, etc.?

If not capitalism, then what else? The whole world is capitalist now. Don't tell me you can escape it?

With reference to Singapore, most students were of the view that Marx's description of capitalism as "exploitative" and "alienating" did not quite "fit" their experience. Many thought this was due to the "moderating" effect of the Singapore government, which in their assessment did not represent the interests of the ruling class, but served all its citizens equally. One very perceptive student noted that Singaporeans could not identify with Marx's thesis about the emiserating effects of capitalism because Singapore was not a "real" developing country. As such, living here, one did not see the "bad side" of capitalistic development, as one would in most Asian and African countries. She also said that Singapore was an advanced, capi- 
talist society, about which Marx was not theorizing. Insights like this, however, were quite rare. With regard to the use of Weberian theory, after having considered the possibility that it was Weber's interpreters who Orientalised his works on the Protestant ethic, students were ready to explore the use of Weber's ideas for the study of development in East Asia. They came to understand that the importance of Weber's work lay in the understanding of the nature of the relationship between religion and development (tutorial 7). In other words, quite apart from the validity of his theory of the Protestant ethic, the question of how religious doctrines and practices relate to economic conduct was one that could be addressed for any religion, and it is this kind of issue that needs to be raised in the context of East Asia. Students often suggested that official interpretations of Islam and Confucianism were meant to align them with corporate values, and that this was a result of formal rationalization processes in modern East Asian and Southeast Asian societies.

On a different theme, most students agreed that Marx, Weber, and Durkheim rightly noted the presence of alienation, disenchantment, and anomie in capitalist society. But they felt that all three theorists were too pessimistic about the effects of these on individuals. According to some, these phenomena may be present in modern society, but were confined to the workplace. Others suggested that people in capitalist societies had developed "coping mechanisms" so that they would not feel anomic, disenchanted or alienated. Others asked if alienation could only be "economic" in nature, suggesting that in non-Western societies there could be other sources of alienation, such as politics and religion. A vast number of students also noted the "datedness" of the theories we were reading. The question of their applicability to contemporary societies (Western and nonWestern) was thus raised. These are crucial elements of our project as they highlight both what we accomplished with our students and, more importantly, what we need to take into account the next time that we teach this course.

\section{CONCLUSION}

We want to emphasize that the ideas carried in this paper reflect a project that is in progress and far from complete. This reflects our initial and experimental effort to conceptualize an alternative way of teaching sociological theory and, more importantly, to put it into practice. Given our own theoretical and political locations, we tried to restructure the syllabus and the course content of social thought and social theory accordingly. We used the theme of Eurocentrism as a major organizing principle as this allowed us to raise a number of related issues about the state of the social sciences and its teaching. It should be noted, however, that this was not the only organizing principle around which the course was developed. We maintained the perspective that guided previous instructors of the course when we stressed to the class that a common thread connecting the works of Marx, Weber, and Durkheim was the problem of freedom in modernity.

When we embarked on this rethinking exercise, we assumed that the course needed to be made relevant and meaningful to the students in order for it to be of some interest and use to them. We conceived of this relevance in terms of the dual stress on the Eurocentric context of the rise of sociological theory as well as the concern with the moral condition of humanity.

How then did the students respond? Did they find the course meaningful? In our assessment the student reactions were mixed, and probably for a number of different reasons. Most students respond to theory in a dull fashion anyway, so the lukewarm response to any course in theory is the norm rather than atypical. It was the same for us. Did our students appreciate discussions of Eurocentrism? Those who saw the problematic of Eurocentrism through the lectures and their own readings and reflections were probably in a minority, and debated the 
issue. Most "got it" when it was pointed out to them via examples and illustrations. Some, however, remained untouched by its theoretical or political value.

Nevertheless, even for those who were less than enthusiastic about the course, the problematic of Eurocentrism was something they could relate to, as it is this theme that brings the ideas of Marx, Weber, and Durkheim within the orbit of relevance in the Southeast Asian context. Our aim was less to make the course more interesting to students than to infuse it with a set of meanings that were hitherto unavailable to them, and which resonated with ideas that were in circulation in critical academic discussions on the state of global social science. Those who saw Eurocentrism as an important issue collectively raised a number of interesting questions:

If one identifies Eurocentric bias in the writings of Marx, Weber and Durkheim, are all their writings meaningless and therefore to be rejected?

We can talk about anti-Eurocentrism. What about a non-Eurocentric position? Is it possible and necessarily better?

What is the value and purpose of locating Eurocentric biases in sociological theory?

Does identifying any kind of bias, including Eurocentrism make the bias go away?

These questions show that at least some of our students were thinking about issues that we raised in the course. We view these queries positively in that they suggest possibilities for rethinking the course. Writing in the late 1990s and early 2000s, one is no longer required to justify the need to identify and critique the biases in which the various social science disciplines are often strongly embedded. Yet criticism alone is insufficient to unseat these biases, as the last student's question so well articulates. But we contend that such critique is empowering and must be the first step in any rethinking process. The fact remains that Eurocentric biases do exist, and that these biases have been ex- posed in the literature. Our aim in this project has not been merely to conduct an exposé of Eurocentrism in a sociological theory course, but to indicate to students how one set of biases needs to be made explicit and not be replaced by another. It was repeatedly stressed that other ethnocentric perspectives need not substitute the critique of Eurocentrism.

Many students suggested that Eurocentrism was unavoidable as Marx, Weber, and Durkheim were simply products of their respective times. We did point out, however, that it is possible for individuals to transcend the dominant consciousness of their time. Furthermore, it is always the case that future generations of thinkers are able to see through the ideological preconceptions and biases of earlier scholars, and present a different reading of the same facts. To some extent, this involves the correction of erroneous conceptions and distortions. However, more than this, future thinkers also bring theoretical perspectives informed by alternative ideological positions. So, while Eurocentrism may have been unavoidable for Marx, Weber, and Durkheim, it is also unavoidable that we engage in its critique, bearing in mind our own context of postcoloniality.

Highlighting Eurocentrism in classical sociological theory is essential to the achievement of our other two previously stated objectives. In this theory course, we were only able to briefly explore how the critique of Eurocentrism can shape our interpretations of the past as well as the present. In showing Marx, Durkheim, and Weber to be Eurocentric in specific ways, we are not suggesting that their ideas or theories should be dismissed or deemed irrelevant for theorizing contemporary society-Western or non-Western. Through our critique, we are searching for ways of reading and rereading the classical sociological theorists that allow us to see continued meaning in their ideas, but with a critical, yet constructive eye. But we do insist that it is imperative that we become sensitized to the Eurocentric biases not just in these classical texts, but also in 
the current readings these texts are subjected to. Most importantly, we wanted to translate this critique into practice, that is, through teaching classical sociological theories with a difference.

\section{REFERENCES}

Alatas, Syed Farid. 1993. "On the Indigenization of Academic Discourse." Alternatives 18(3):307-38.

. 1995. "The Sacralization of the Social Sciences: A Critique of an Emerging Theme in Academic Discourse." Archives de Sciences Sociales des Religions 91:89-111.

Alatas, Syed Hussein. 1956. "Some Fundamental Problems of Colonialism." Eastern World 10:9-10.

1972. "The Captive Mind in Development Studies." International Social Science Journal 34(1):9-25.

1974. "The Captive Mind and Creative Development." International Social Science Journal 36(4):691-99.

1979. "Towards an Asian Social Science Tradition." New Quest 17:265-69.

. 1981. "Social Aspects of Endogenous Intellectual Creativity: The Problem of Obstacles-Guidelines for Research.” Pp. 462-70 in Intellectual Creativity in Endogenous Culture, edited by A. Abdel-Malek and A.N. Pandeya. Tokyo, Japan: United Nations University.

Asante, Molefi Kete. 1990. Kemet, Afrocentricity and Knowledge. Trenton, NJ: Africa Wood Press.

Atal, Yogesh. 1981. "The Call for Indigenization." International Social Science Journal 33(1):189-97.

Bell, Morag. 1994. "Images, Myths and Alternative Geographies of the Third World." Pp. 174-99 in Human Geography: Society, Space and Social Science, edited by Derek Gregory, Ron Martin and G. Smith. London, England: Macmillan.

Ben Jelloun, Taher. 1974. "Décolonisation de la Sociologie au Maghreb: Utilité et Risques d'une Fonction Critique." Le Monde Diplomatique August, Pp. 28-33.

Bennagen, P.L. 1980. "The Asianization of Anthropology." Asian Studies 18:1-26.

Blake, Myrna L. 1991. "The Portability of Family Therapy to Different Cultural and SocioEconomic Contexts." Asia-Pacific Journal of Social Work 1(2):32-60.
Buss, Andreas. 1984. “Max Weber's Heritage and Modern Southeast Asian Thinking on Development." Southeast Asian Journal of Social Science 12(1):1-15.

Dube, S.C. 1984. "India." Pp. 229-48 in Social Sciences in Asia and the Pacific. Paris, France: UNESCO.

Dumont Jr, Clayton, W. 1995. "Toward a Multicultural Sociology: Bringing Postmodernism into the Classroom." Teaching Sociology 23:307-20.

Durkheim, Emile. 1933. The Division of Labour in Society. New York: Free Press. . 1952. Suicide: A Study in Sociology. New York: Routledge and Kegan Paul. [1895] 1982. The Rules of Sociological Method. New York: Free Press.

Fei, Hsiao-t'ung [Fei Xiaotong]. [1947] 1979. "The Growth of Chinese Sociology." Pp. 1931 in Fei Hsiao-t'ung: The Dilemma of $a$ Chinese Intellectual, selected and translated by James P. McGough. White Plains, New York: M.E. Sharpe.

Fu, Daiwie. 1993. "Local Contexts, Strategies and Sinicization: A Case Study of the Sinicization Formulation in the Social Sciences of Taiwan (1970s - 1980s)." Pp. 245-64 in Philososphy and Conceptual History of Science in Taiwan, edited by Cheng-Hung Lin and Daiwie Fu. Kluwer, Netherlands: Kluwer Academic Publishers, at The Hague.

Ghosh, Suniti Kumar. 1984. "Marx on India." Monthly Review 35:39-53.

Hirschman, Charles. 1986. "The Making of Race in Colonial Malaya: Political Economy and Racial Ideology." Sociological Forum 1(2):330-61.

Kahn, Herman. 1979. World Economic Development: 1979 and Beyond. London, England: Croom Helm.

Karim, A.K. Nazmul. 1984. “Bangladesh.” Pp. 79-92 in Social Sciences in Asia and the Pacific. Paris, France: UNESCO.

Khatibi, M. 1967. Bilan de la Sociologie au Maroc. Rabat, Morocco: Publications de l'Association pour la Recherche en Sciences Humaines.

Kyi, Khin Maung. 1984. "Burma." Pp. 93-141 in Social Sciences in Asia and the Pacific. Paris, France: UNESCO.

Lewis, Jonathan F. and Musa Alshtawi. 1992. "Then and Now: The Treatment of Selected Theorists in American Social Theory Texts." Teaching Sociology 20:44-50.

Lie, John. 1995. "American Sociology in a Transnational World: Against Parochialism." 
Teaching Sociology 25:136-44.

1996. "Sociology of Contemporary

Japan." Current Sociology 44(1):1-95.

Martin, William G. 1996. "Toward a 'Global' Curriculum and Classroom: Contrasting Comparative and World-Historical Strategies." Teaching Sociology 24:145-47.

Marx, Karl. 1970. A Contribution to the Critique of Political Economy. Moscow, Russia: Progress Publishers.

1973. Grundrisse: Foundations of the Critique of Political Economy. New York: Vintage.

Marx, Karl and Frederick Engels. 1968. On Colonialism. Moscow, Russia: Progress Publishers.

Parker, David. 1997. "Viewpoint: Why Bother with Durkheim? Teaching Sociology in the 1990s." Sociological Review 45(1):122-46.

Rana, Ratna S.J.B. 1984. "Nepal." Pp. 354-73 in Social Sciences in Asia and the Pacific. Paris, France: UNESCO.

Ritzer, George. 1983. Sociological Theory. New York: Alfred A Knopf.

Rizal, Jose. [1890] 1962. "To the Filipinos," p. vii. in Historical Events of the Philippine Islands, Writings of Jose Rizal, vol. VI, Manila, Philippines: National Historical Institute.

Rudolph, Lloyd and Susanne Rudolph. 1967. "The Place of Tradition in Modernization." Development Digest 5:62-66, Washington, DC: National Planning Association.

Sanda, A. Muiwya. 1988. "In Defense of Indigenization in Sociological Theories." International Sociology 3(2):189-99.

Sarkar, Benoy Kumar. [1937] 1985. The Positive Background of Hindu Sociology. Delhi, India: Motilal Banarsidass.

Uberoi, J.P. 1968. "Science and Swaraj." Contributions to Indian Sociology (2):119-23.

Sinha, Vineeta. 1997. "Reconceptualising the Social Sciences in Non-Western Settings: Challenges and Dilemmas." Southeast Asian Journal of Social Science 25(1):167-82.

2000. "Reading Harriet Martineau: Paral-

lels in Counter-Androcentric and CounterEurocentric Discourses." Unpublished Conference Paper, presented at the Third Asia-Pacific Regional Conference of Sociology, Cheju City, South Korea, February 4-6.

Tiryakian, Edward. 1994. "Revisiting Sociology's First Classic: The Division of Labour in
Society and its Actuality." Sociological Forum 19(1):3-15.

University of Delhi. N.d. Scheme of Examination and Courses of Reading for B.A. (Hons.) Examination in Sociology. Delhi, India: University of Delhi.

University of Dhaka. 1988. Syllabuses of the Department of Sociology. Dhaka, Bangladesh: University of Dhaka.

Wallerstein, Immanuel. 1996. "Eurocentrism and Its Avatars: The Dilemmas of Social Science." Paper presented to the Korean Sociological Association-International Sociological Association East Asian Regional Colloquium on "The Future of Sociology in East Asia," Seoul, South Korea, November 22-23.

Weber, Max. 1951. The Religion of China: Confucianism and Taoism. New York: The Free Press.

. 1958a. The Protestant Ethic and the Spirit of Capitalism. New York: Charles Scribner's Sons.

. 1958b. The Religion of India: The Sociology of Hinduism and Buddhism. Translated and edited by Hans Gerth and Don Martindale, New York: The Free Press.

. 1969. "Objectivity in Social Science and Social Policy." Pp. 49-61 in The Methodology of the Social Sciences, New York: The Free Press.

Zawiah, Yahya. 1994. Resisting Colonialist Discourse. Bangi, Malaysia: Penerbit Universiti Kebangsaan Malaysia.

Syed Farid Alatas is an associate professor at the department of sociology, National University of Singapore. A Malaysian national, he had his schooling in Singapore and obtained his $\mathrm{Ph} . \mathrm{D}$. in sociology from the Johns Hopkins University in 1991 . He lectured at the University of Malaya in the department of Southeast Asian Studies prior to his appointment at Singapore. He has contributed articles to a number of scholarly journals, and his book Democracy and Authoritarianism: The Rise of the Post-Colonial State in Indonesia and Malaysia was published by Macmillan in 1997. He is currently working on a second book in the area of the philosophy and sociology of social science.

Vineeta Sinha is a lecturer at the department of sociology, National University of Singapore. She obtained her Ph.D. in anthropology from the Johns Hopkins University in 1995. Her research interests include the critique of concepts and categories in the social sciences, the sociology and anthropology of religion, and theorizing health and healing. 